medgen $2018 \cdot 30: 12-20$

https://doi.org/10.1007/s11825-018-0181-7

Published online: 26 February 2018

(c) The Author(s) 2018. This article is an open access publication.

CrossMark

Frank Tüttelmann · Christian Ruckert · Albrecht Röpke

Institute of Human Genetics, University of Münster, Münster, Germany

\title{
Disorders of spermatogenesis
}

\section{Perspectives for novel genetic diagnostics after 20 years of unchanged routine}

because testicular biopsies to obtain spermatozoa are performed there. The distribution of phenotypes from semen analyses of men in infertile couples attending the CeRA is shown in - Fig. 1a.

Semen analysis should be accompanied by measurement of serum hormone levels of at least the pituitary-produced gonadotrophins luteinising hormone (LH) and follicle-stimulating hormone (FSH) in addition to testosterone [48]. If spermatogenesis is reduced, FSH increases because of the hypothalamic-pituitary-gonadal feedback loop. Thus, in a large fraction of about $60 \%$ of infertile men, hypergonadotropic oligo- or azoospermia are found. Men with this type of severe spermatogenic failure may also exhibit reduced testicular volume, decreased serum testosterone and increased LH levels as a sign of broader testicular dysfunction, i.e. hypogonadism. Hypergonadotropic azoospermia can also be termed "non-obstructive azoospermia” (NOA). In contrast, obstructive azoospermia (OA) is suspected if FSH levels and testicular volume are normal. OA is mainly caused by the physical blockage of the male excurrent ductal system. Affected men have quantitatively and qualitatively normal spermatogenesis (• Fig. 2a). Obstructive azoospermia is most commonly caused by mutations in the CFTR gene, which lead to incomplete formation of the vas deferens and congenital bilateral absence of the vas deferens (CBAVD), an association first described 50 years ago [19].

Azoospermia, which can be considered the clinically most severe phenotype of male infertility because natural conception cannot occur, has been es- timated to affect 0.1 to $1 \%$ of all men and $10-15 \%$ of men in infertile couples [50]. In men with azoospermia, the definitive (albeit still descriptive) diagnoses can only be determined by testicular biopsy, which is usually performed to obtain spermatozoa (testicular sperm extraction, TESE). These are needed for intracytoplasmic sperm injection (ICSI), one form of assisted reproductive technology (ART), where one sperm is injected into an oocyte. The most common histological classifications are:

1. "Mixed atrophy" (tubules with varying stages of spermatogenesis).

2. Various types of "spermatogenic arrest" (such as round spermatid or meiotic arrest, MA, - Fig. $\mathbf{2 b}$, these stages being the most advanced that can be found).

3. "Sertoli cell-only syndrome" (SCOS, in which the tubules contain no germ cells at all, - Fig. 2c).

These can be global (present in all tubules) or focal, with a variable percentage of tubules displaying various stages of qualitatively and quantitatively limited spermatogenesis [5].

All of the descriptive categories mentioned help to classify the "male factor" in couple infertility, but do not offer any causal diagnoses for disturbed spermatogenesis (or causes of obstruction) in the affected men. However, elucidating the cellular/molecular cause of spermatogenic impairment is rather difficult. The testis is not only composed of the two distinct compartments of the interstitium (containing amongst others the testosterone-producing Leydig cells) and the seminiferous tubules (containing the somatic Sertoli cells and the germ cells), but spermatogenesis is one of the most complex differentiation processes 
Table 1 The most important WHO reference ranges for semen analysis

\begin{tabular}{l|l}
\hline Semen parameter & Reference range \\
\hline Semen volume & $\geq 1.5 \mathrm{ml}$ \\
\hline $\mathrm{pH}$ & $\geq 7.2$ \\
\hline Sperm concentration & $\geq 15$ million sperm $/ \mathrm{ml}$ \\
\hline Total sperm count & $\geq 39$ million sperm/ejaculate \\
\hline Total sperm motility & $\geq 40 \%$ motile sperm \\
\hline Progressive sperm motility & $\geq 32 \%$ progressively motile sperm (former categories a $+\mathrm{b}$ ) \\
\hline Sperm morphology & $\geq 4 \%$ morphologically normal sperm
\end{tabular}

in which cells transform from spermatogonia through several stages to mature spermatozoa and undergo meiosis in between. Accordingly, spermatogenesis is thought to be orchestrated by a multitude of up to 2000 genes, of which 600 to 900 seem to be exclusively expressed in the male germline $[7,28,39,57]$. Thus, the genetics of "male infertility" are difficult to tackle.

\section{Current clinical diagnoses and genetic routine analyses}

Male infertility can be caused by genetic defects that increase in prevalence when spermatogenesis is severely impaired. Currently, a specific causal diagnosis can be attributed to about $28 \%$ of unselected infertile men according to our own large dataset. Only very few comparable, large-scale epidemiological studies are available that address this topic, but they report frequencies in the same order of magnitude [32]. These mostly consist of previous gonadotoxic chemo- or radiotherapy for the treatment of malignant disease (including testicular tumours; $\sim 10 \%$ ) and several other causes such as general/chronic diseases (e.g. diabetes) or testosterone abuse $(\sim 14 \%)$. Currently, only about $4 \%$ of causal genetic diagnoses can be established ( $\bullet$ Fig. 1b). These comprise structural and numerical chromosomal aberrations (e.g. Klinefelter syndrome; karyotype 47, XXY), microdeletions of the aoospermia factor (AZF) regions on the long arm of the $\mathrm{Y}$ chromosome, and mutations of the CFTR gene in obstructive azoospermia (for further reading see Tournaye et al. [45]). AZF microdeletions have been reported in highly variable prevalence depending on geographic origin and on selection criteria. It has been shown several times that the deletion frequency in Germany seems to be rather low in comparison to other regions [22, 40]. In addition, a large number of genes involved in the migration and function of GnRH neurons or their hypothalamic targets have been discovered that may be mutated in patients with congenital hypogonadotropic hypogonadism $(\mathrm{CHH})$ with or without anosmia (for current reviews see $[6,38])$. In azoospermic men, the genetic diagnostic yield increases to about $20 \%$ (๑ Table 2). All of these causes can be identified by wellestablished genetic tests and form the widely applied clinical routine analyses. Other genetic causes of male infertility comprise disorders of androgen action, genetic syndromes that include infertility as a symptom, and specific defects of sperm morphology and function. Furthermore, mutations and polymorphisms of various genes have been found to be associated with unspecific spermatogenic failure/male infertility, but none of these has been introduced into the clinical work-up of infertile males so far. Thus, in about $72 \%$ of men in infertile couples, no causal diagnoses can be established and the aetiology of disturbed spermatogenesis remains largely unclear.

\section{Monogenic causes of spermatogenic failure}

In the field of male infertility, sequencing of genes in clinical setting is currently performed in the very rare condition of $\mathrm{CHH}$, in which gene panels have been introduced into clinical routine in the last few years $[6,41]$. In addition, analysis of the CFTR gene is routinely performed in men with obstructive azoospermia and mutations in the ADGRG2 gene have been recently described to cause a similar phenotype [8]. However, for most patients with the common phenotypes of oligoand azoospermia, no specific genetic sequencing strategy exists thus far. Indeed, no genetic causes relevant to the clinical diagnostic work-up, treatment decisions or counselling with regard to the reproductive health of offspring have been identified in over 20 years $[11,29,30,48]$ when AZF deletions were described as a common cause of spermatogenic failure [54]. This is especially surprising because it was estimated long ago that overall about $30 \%$ of cases of male infertility are caused by chromosomal abnormalities or mutations of genes involved in germ cell production and function [53] and familial clustering of male infertility was shown in some case-control studies [16, 17, 25]. In the case of azoospermia in particular, a genetic origin can be suspected in most affected men. Thus, there is a large gap of genetic diagnoses ranging from $\sim 25 \%$ in unselected infertile men to $\sim 70 \%$ in azoospermic men. This may be partially explained by two important differences in comparison to studying other phenotypes:

(1) Classical linkage analysis or association studies are difficult in infertility because large families with infertility are by nature uncommon.

(2) The parents of an infertile man (and woman) - as the rest of the family are usually not informed of a patient's problem conceiving a child.

As described above, male infertility should be considered a complex, multifactorial and clinically and genetically heterogeneous disease. Not surprisingly, single candidate gene approaches did not identify novel genetic causes of infertility $[4,21]$. At the level of single-nucleotide polymorphisms (SNPs), our review and meta-analysis from $2007 \mathrm{did}$ not provide any clinically significant associations [47]. Likewise, during the last few years, six genome-wide association studies (GWAS) of highly variable numbers of patients did not reveal an over- 
medgen 2018 - 30:12-20 https://doi.org/10.1007/s11825-018-0181-7

(c) The Author(s) 2018. This article is an open access publication.

\section{F. Tüttelmann · C. Ruckert · A. Röpke}

\section{Disorders of spermatogenesis. Perspectives for novel genetic diagnostics after 20 years of unchanged routine}

\section{Abstract}

Infertility is a common condition estimated to affect $10-15 \%$ of couples. The clinical causes are attributed in equal parts to the male and female partners. Diagnosing male infertility mostly relies on semen (and hormone) analysis, which results in classification into the two major phenotypes of oligo- and azoospermia. The clinical routine analyses have not changed over the last 20 years and comprise screening for chromosomal aberrations and Y-chromosomal azoospermia factor deletions. These tests establish a causal genetic diagnosis in about $4 \%$ of unselected men in infertile couples and $20 \%$ of azoospermic men. Gene sequencing is currently only performed in very rare cases of hypogonadotropic hypogonadism and the CFTR gene is routinely analysed in men with obstructive azoospermia. Still, a large number of genes have been proposed to be associated with male infertility by, for example, knockout mouse models. In particular, those that are exclusively expressed in the testes are potential candidates for further analyses. However, the genome-wide analyses (a few array-CGH, six GWAS, and some small exome sequencing studies) performed so far have not lead to improved clinical diagnostic testing. In 2017, we started to routinely analyse the three validated male infertility genes: NR5A1, DMRT1, and TEX11. Preliminary analyses demonstrated highly likely pathogenic mutations in these genes as a cause of azoospermia in 4 men, equalling $5 \%$ of the 80 patients analysed so far, and increasing the diagnostic yield in this group to $25 \%$. Over the past few years, we have observed a steep increase in publications on novel candidate genes for male infertility, especially in men with azoospermia. In addition, concerted efforts to achieve progress in elucidating genetic causes of male infertility and to introduce novel testing strategies into clinical routine have been made recently. Thus, we are confident that major breakthroughs concerning the genetics of male infertility will be achieved in the near future and will translate into clinical routine to improve patient/couple care.

Keywords

Male infertility · Oligozoospermia . Azoospermia

\section{Spermatogenesestörungen. Perspektiven für erweiterte genetische Diagnostik nach 20 Jahren unveränderter Routine}

\section{Zusammenfassung}

Etwa $10-15 \%$ aller Paare erzielen auf natürlichem Weg keine Schwangerschaft und sind nach WHO-Definition als "sub-/infertil" einzustufen. Klinische Ursachen werden bei diesen Paaren etwa zur Hälfte bei der Frau bzw. beim Mann nachgewiesen. Die klinischen Untersuchungen bei männlicher Infertilität beschränken sich derzeit auf Ejakulat- und Hormonuntersuchungen, die dann bei einer Vielzahl der Männer zur deskriptiven „Diagnose" Oligozoo- oder Azoospermie führen, wodurch die Ursache der Infertilität des Paares erklärt werden kann. Der eigentliche Grund für die Spermatogenesestörung bleibt damit aber unklar. Die genetische Diagnostik bei infertilen Männern hat sich in den letzten 20 Jahren nicht weiter entwickelt und umfasst nach wie vor ausschließlich das Screening hinsichtlich Chromosomenstörungen und Y-chromosomaler AZF-Deletionen. Diese beiden Untersuchungen finden die tatsächliche Ursache der Spermatogenesestörung bei etwa $4 \%$ der unselektierten Männer und bei etwa $20 \%$ der Männer mit Azoospermie. Gensequenzierungen werden hingegen bislang ausschließlich bei Patienten mit hypogonadotropem Hypogonadismus, einem umschriebenen, sehr seltenen Krankheitsbild, bzw. bei obstruktiver Azoospermie (CFTRAnalytik) durchgeführt. Andererseits wurden bereits viele Gene publiziert, in denen Mutationen potenziell zu einer Infertilität des Mannes führen können. Allerdings haben die bislang publizierten Daten und auch die genomweiten Analysen keine Erweiterung der klinischen Diagnostik erreicht. Seit Anfang 2017 haben wir drei Kandidatengene NR5A1, DMRT1 und TEX11 - bei Männern mit Azoospermie sequenziert. Die vorläufigen Auswertungen ergaben vier wahrscheinlich pathogene Mutationen in diesen Genen. Dies entspricht $5 \%$ der 80 bislang ausgewerteten Männer. Die kausalen Diagnosen steigen bei dieser Patientengruppe somit auf etwa $25 \%$. In den vergangenen Jahren wurden zunehmend weitere Kandidatengene publiziert. Gleichzeitig laufen mehrere große Studien bei infertilen Männern. Deswegen gehen wir davon aus, dass in naher Zukunft weitere klinisch relevante Erkenntnisse gewonnen werden, die dann auch Einzug in die Routinediagnostik finden und die Behandlung dieser Männer bzw. des Paares verbessern werden.

Schlüsselwörter

Männliche Infertilität · Oligozoospermie · Azoospermie lap among the highest ranking genes that were reported to be "associated with male infertility" (- Fig. 3; [1, 2, 10, 18, 20, $38,60])$. Moreover, either no replication studies have been performed so far or mostly did not confirm the identified candidate genes. Reasons probably include:
1. Genetic variants negatively affecting male reproductive fitness are selected against during evolution and are, therefore, not included in the set of common SNPs used in GWAS.

2. The cohorts were too small to detect genetic variants with a small effect size, and/or
3. Patient selection was too broad owing to poorly defined phenotypes ("men with azoospermia", testicular histology not known).

Overall, genome-wide approaches with the aim of identifying novel candidate genes have not been applied frequently 


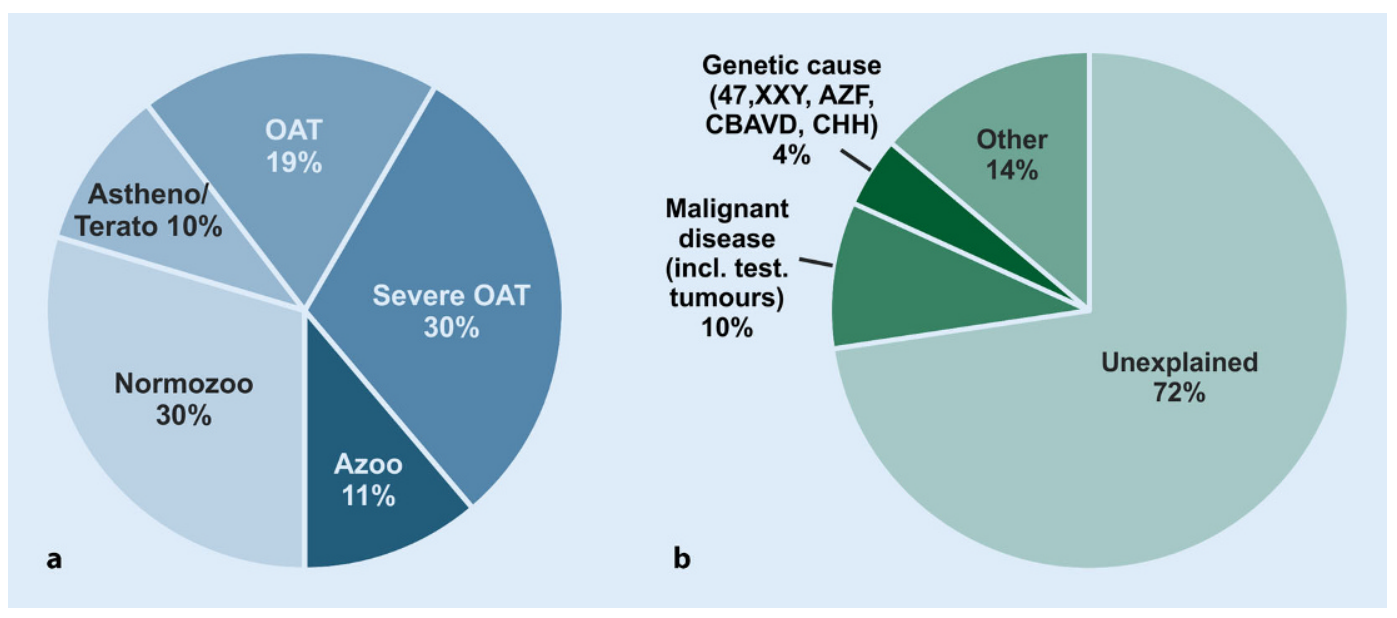

Fig. $1 \Delta$ a Descriptive diagnoses according to semen analyses of 26,091 men in infertile couples who attended the Centre of Reproductive Medicine and Andrology (CeRA), Münster over the last 30 years. b Clinical diagnoses in the same men. Data from Androbase $^{\circledR}$, the clinical patient database [46]
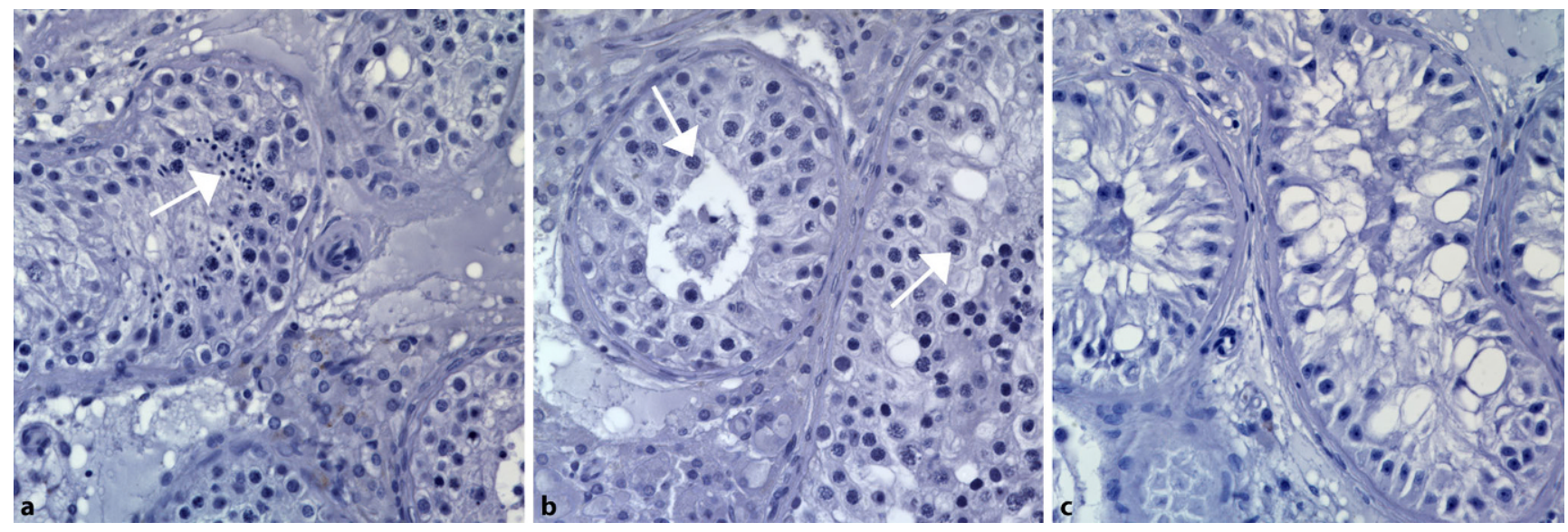

Fig. 2 A Histological images (CeRA) of human testicular tissue sections from patients with (a) obstructive azoospermia and quantitatively and qualitatively normal spermatogenesis, $\mathbf{b}$ meiotic arrest, and c Sertoli cell-only syndrome. Most advanced germ cell types (a elongated spermatids, $\mathbf{b}$ spermatocytes) are indicated by white arrows

in male infertility. Still, and as in other genetic disorders, the power of such approaches has been demonstrated by genome-wide array-comparative genomic hybridisation (array-CGH) in groups of clinically well-characterised oligo- and azoospermic men. We were the first to report an excess of copy number variations (CNVs) especially on the sex-chromosomes [49], which has been confirmed by others [15, 27]. However, aside from DMRT1 (see above) and TEX11 (see below) no deletions in genes have yet been confirmed in independent studies.

In other heterogeneous diseases, such as RASopathies and primary ciliary dyskinesia (PCD), and multifactorial diseases, such as hearing loss, large ad- vances in genetic diagnostics have been observed in the last few years because of the recent technological developments of large scale sequencing approaches made available through next-generation sequencing (NGS). Consequently, the genetic diagnostic yield has increased to about $30 \%$ even in polygenic multifactorial diseases such as intellectual disability, which is in stark contrast to male infertility (• Fig. 4). Taking this into account, large-scale whole-exome sequencing (WES) studies are currently lacking in male infertility and only very few novel candidate genes have been described, mostly in small studies, sometimes in single consanguineous families. Current examples are TEX15 [31] and NPAS2 [33] in non-obstruc- tive azoospermia and ADGRG2 [8] in obstructive azoospermia.

\section{Towards a gene panel for male infertility}

To date and to our knowledge, only three genes have been identified that fulfil the following criteria:

1. Biological evidence for the putative association with male infertility (e.g. knock-out mouse model shows male infertility).

2. Replicated in an independent study.

3. Functional evidence that identified variants are pathogenic. 
Table 2 Genetic causes identified by current routine analyses (patients of the Centre of Reproductive Medicine and Andrology [CeRA] Münster)

\begin{tabular}{|c|c|c|}
\hline Genetic diagnosis & $\begin{array}{l}\text { Unselected } \\
\text { patients } \\
(N=26,091) \\
(\%)\end{array}$ & $\begin{array}{l}\text { Azoospermic } \\
\text { patients } \\
(N=3252) \\
(\%)\end{array}$ \\
\hline Chromosomal aberrations & 2.8 & 15.0 \\
\hline Klinefelter syndrome $(47, \mathrm{XXY})$ & 2.6 & 13.7 \\
\hline XX-Male $(46, X X)$ & 0.1 & 0.6 \\
\hline Translocations & 0.1 & 0.3 \\
\hline Others & $<0.1$ & 0.4 \\
\hline $\begin{array}{l}\text { Isolated congenital bilateral absence of the vas deferens or } \\
\text { cystic fibrosis }\end{array}$ & 0.5 & 3.1 \\
\hline $\begin{array}{l}\text { Congenital hypogonadotropic hypogonadism } \\
\text { including Kallmann syndrome }\end{array}$ & 0.7 & 0.9 \\
\hline Y-chromosomal azoospermia factor deletions & 0.3 & 1.6 \\
\hline Total & 4.3 & 20.6 \\
\hline
\end{tabular}

\section{NR5A1}

The gene NR5A1 (nuclear receptor subfamily 5 , group A, member 1 , OMIM 184757) encodes the steroidogenic factor 1 (SF1) protein. Mutations in NR5A1 are well known to cause autosomaldominant primary adrenal insufficiency and 46, XY disorders of sexual development, and later also in men with hypospadias, bilateral anorchia and micropenis in addition to women with primary ovarian insufficiency [13]. In 2010, heterozygous missense mutations were found in $4 \%$ of French infertile men with unexplained reduced sperm counts, but all mutation carriers were of non-Caucasian ancestry [3]. Therefore, we performed a comprehensive NR5A1 sequence analysis in almost 500 well-characterised and predominantly Caucasian patients with azoospermia or severe oligozoospermia [37]. Along with several synonymous variants of unclear pathogenicity, three rare heterozygous missense mutations were identified that were affecting conserved amino acids and predicted to be damaging to SF1 protein function. The semen phenotype of mutation carriers seems variable, but all three men had azoospermia or severe oligozoospermia (sperm concentration below $1 \mathrm{million} / \mathrm{ml}$ ). Overall, the mutation frequency in our patient group was about $1 \%$, depending on the subgroups analysed. Another study in Italian men confirmed NR5A1 mutations as a cause of severe spermatogenic failure [12].

Of note, clearly detrimental NR5A1 (nonsense) mutations or deletions are not expected in this group of infertile but otherwise healthy men because such mutations would cause the more severe phenotypes mentioned above. Functional evidence that missense mutations actually impair SF1 transcriptional activity on target genes compared with wildtype SF1 has been provided in at least two independent studies [3,12].

\section{DMRT1}

The gene DMRT1 (doublesex- and MAB3-related transcription factor 1 , OMIM 602424) encodes another transcription factor that plays a key role in testis differentiation and is expressed mainly in the testes. Deletions of the short arm of chromosome 9 encompassing DMRT1 are well-known to be associated with $9 \mathrm{p}$ deletion syndrome and XY gonadal dysgenesis [23, 52]. Consecutively, in 2013, smaller deletions in DMRT1 were identified in five infertile men with azoospermia but no symptoms of gonadal dysgenesis [27]. At the same time, we hypothesised $D M R T 1$ to be an interesting candidate gene for male spermatogenic failure and sequenced this gene in around 300 infertile patients with azoo- or cryptozoospermia (sperm concentration below $0.1 \mathrm{mill} / \mathrm{ml}$ ) [43]. In total, we detected four rare, putative pathogenic missense mutations in six patients (3.5\%), two of which, however, were also found in controls (men with normal spermatogenesis). Those two mutations not detected in controls were exclusively found in men with azoospermia ( 1\%). Another study screened azoospermic men for DMRT1 exonic insertions and deletions (by MLPA, $n=68$ ) and point mutations (by Sanger sequencing, $n=155$ ) and found only non-coding or synonymous substitutions. However, these were overrepresented in patients when compared with almost 400 controls [26]. To date, it remains to be clearly demonstrated whether heterozygous mutations or deletions in DMRT1 are sufficient to cause gonadal dysgenesis or spermatogenic failure. Although the same problem of mostly identifying missense mutations, which are more difficult to interpret per se (see above), DMRT1 remains one of the highest ranking candidate genes for both conditions.

\section{TEX11}

In a collaborative study involving our colleagues from the Magee-Womens Research Institute, Pittsburgh, PA, USA (led by Alexander Yatsenko), the CeRA and ourselves, mutations in the $\mathrm{X}$-linked gene TEX11 (testis-expressed gene 11, OMIM 300311) were identified to be a cause of meiotic arrest and azoospermia [59]. In the first step of this study, high-resolution array-CGH was used to screen men with non-obstructive azoospermia, revealing a recurring deletion of three exons of TEX11 in two patients. Because TEX11 protein was previously shown to be required for completing meiosis in a knock-out mouse model, it immediately became an interesting candidate for further analysis. By sequencing TEX11 in a larger group of almost 300 azoospermic men, more clearly pathogenic (truncating and splice) mutations were detected, whereas no mutations were found in controls. Overall, mutations in TEX11 were identified in more than $2 \%$ of azoospermic men and in as many as $15 \%$ of patients with meiotic arrest. This breakthrough relied on the combination of genetics and phenotyping by testicular 


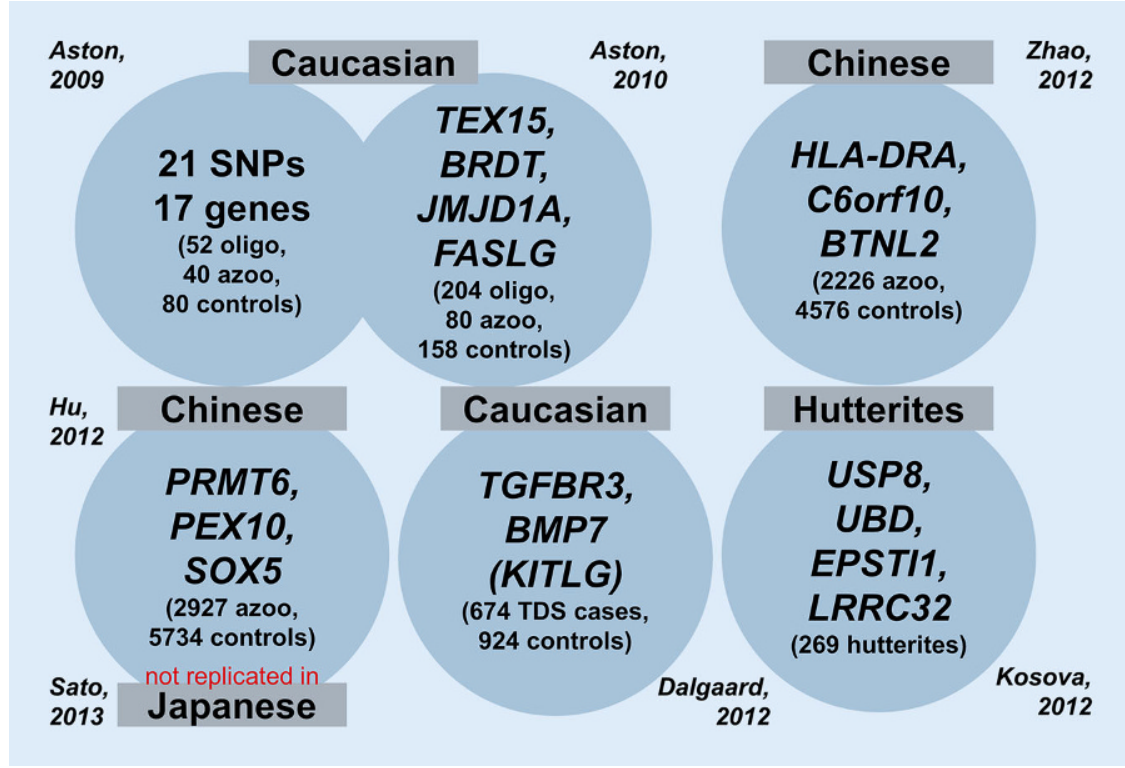

Fig. $3 \Delta$ Genome-wide association studies (GWAS) in male infertility show no overlap between identified candidate genes so far (number of cases/controls analysed in brackets). oligo oligozoospermia, azoo azoospermia, TDS testicular dysgenesis syndrome

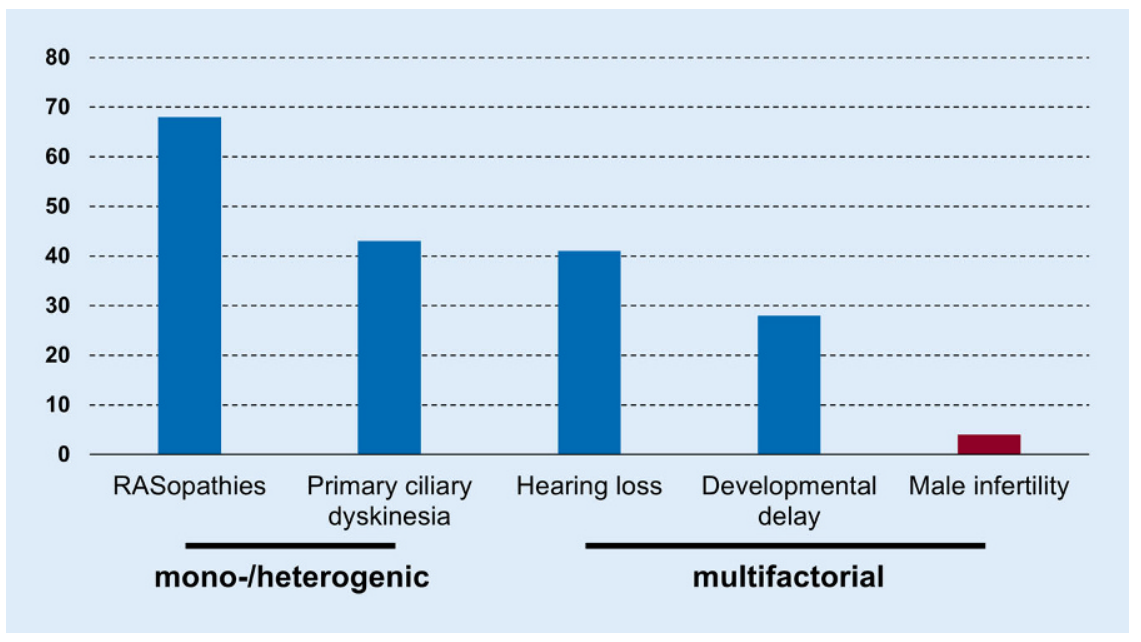

Fig. $4 \Delta$ Detection rates of molecular diagnostic tests (\%; adapted from Rehm [35])

histology. TEX11 mutations were already confirmed to be a common cause of azoospermia in an independent study by Yang et al. [58]. The authors also provided evidence that TEX11 protein levels modulate genome-wide recombination rates in both sexes. Thus, hemizygous mutations in the TEX11 are to date the first X-chromosomal and major single gene defect in azoospermia.

\section{First results of a small gene panel of NR5A1, DMRT1, and TEX11}

In preparation for the recently established Clinical Research Unit "Male Germ Cells: from Genes to Function" (German Research Foundation, DFG CRU326), we expanded our analyses of clinically well-characterized men with unexplained azoospermia who attended the CeRA. Patients with known causes of male infertility, such as chemo- or radiotherapy, were excluded in advance. Since January 2017, a total of 323 men with unexplained azoospermia presented at the CeRA for the first time. Initially, the routine chromosomal and AZF analyses were performed. Overall, 46 patients $(\sim 14 \%)$ were identified with numerical (almost exclusively 47, XXY) or structural aberrations (46, XX; aberrant $\mathrm{Y}$ chromosomes; translocations; inversions). AZF deletions were found in almost 2\% (6 out of 310 ).

In a second step, sequence analysis of three genes, NR5A1, DMRT1, and TEX11, was offered and carried out in consenting men with apparently normal karyotypes and without AZF deletions. Up to December 2017, over 150 men agreed to participate about 80 of whom have been analysed thus far. All nonpolymorphic variants (i.e. rare, below $1 \%$ minor allele frequency in public and our in-house databases) were strictly classified under clinical conditions according to the American College of Medical Genetics and Genomics guidelines for the interpretation of sequence variants [36]. Potentially pathogenic variants were identified in the DMRT1 and TEX11 genes (one each) and two different mutations in the NR5A1 gene (in one man each).

In conclusion, the basic genetic analyses in men with non-obstructive azoospermia using conventional cytogenetic analysis and AZF screening revealed the expected number of aberrations. Sequencing of these three genes, which have been confirmed to be responsible for spermatogenetic failure, a highly likely cause of azoospermia, could be demonstrated in 4 patients, equalling $5 \%$ of the patients analysed so far and increasing the diagnostic yield in this patient group to $25 \%$.

\section{Outlook: \\ clinical relevance, recent progress, concerted actions}

To date, genes that have been found to be mutated in infertile men in one study have mostly not been validated in an independent study. Several potential drawbacks may serve as explanation: patient selection was too broad because of poorly defined phenotypes (e.g. "men with azoospermia", but testicular histol- 
ogy was not known) and/or the number of patients analysed was too small to detect rare genetic variants. The latter seems especially important as it becomes increasingly clear that aside from $\mathrm{X}$-chromosomal causes (e.g. TEX11) [59] and consanguineous families with probably very rare autosomal-recessive causes (e.g. TEX15) [31], autosomaldominant causes may constitute the majority in male infertility. Thus, rare de novo mutations with dominant effects may well explain a large fraction of nonobstructive azoospermia and potentially also milder forms of male infertility such as oligozoospermia. This would be comparable with many other common, genetically highly heterogeneous diseases such as intellectual disability [24, 34, 51].

All of the currently established genetic diagnoses in infertile males have direct prognostic value for the patients and for the health of the offspring $[44,45]$. Men with CBAVD carrying CFTR mutations have very high chances of successful testicular sperm extraction (TESE), but also significantly increased risks for cystic fibrosis (CF) in their children, depending on the CFTR carrier status of their partner. Men with Klinefelter syndrome, previously thought to have no chance of fathering children, now have an estimated chance of around $50 \%$ of successfully obtaining spermatozoa by (microsurgical) TESE. Depending on the type of deletion, azoospermic men carrying AZF deletions have virtually zero $(\mathrm{AZFa} / \mathrm{b})$ to up to $50 \%$ (AZFc) chance of TESE and their sons will inherit the deletion and likely also be infertile [22]. Thus, even though the detection of a genetic alteration does not substantially change the treatment in most cases, the clinical value lies in:

1. Establishing a definitive causal diagnosis.

2. The prognostic value comprising chances of testicular sperm extraction and pregnancy.

3. Assessing the risks for the offspring in the case of successful treatment.

During the last few years, we observed a steep increase in publications on novel candidate genes for male infertility, especially in men with azoospermia. This is mostly due to application of NGS strategies, and, in comparison with earlier times, better characterised patient groups. Examples comprise the already mentioned TEX15, NPAS2, and $A D$ GRG2 genes. However, regarding all other previously proposed candidate genes, such as SOHLH1 [9], USP26 [42], MEIOB, TEX14, and DNAH6 [14], validation in another (ideally larger) study is urgently warranted.

Fortunately, concerted efforts to achieve progress in elucidating genetic causes of male infertility and introduce novel testing strategies into clinical routine have been recently established. Don Conrad (Washington University School of Medicine, St. Louis, MI, USA) and Ki Aston (University of Utah, Salt Lake City, UT, USA) lead the NIH-funded "Genetics of Male Infertility Initiative" (GEMINI, http://gemini.wustl.edu), we have recently been granted the DFG-funded Clinical Research Unit "Male Germ Cells: from Genes to Function" (CRU326, http://male-germ-cells.de), and Joris Veltman (Newcastle University, Newcastle upon Tyne, UK and Radboud University Medical Centre, Nijmegen, The Netherlands) has very recently received the Wellcome Trust grant "Unravelling genetic causes and risk factors for severe male infertility". The same investigators, together with Moira O'Bryan (Monash University, Melbourne, Australia) and Ewa Rajpert-De Meyts (Copenhagen University Hospital [Rigshospitalet], Copenhagen, Denmark), also recently founded the "International Male Infertility Genomics Consortium" (IMIGC, http://infertilegenome.org), which is aimed at the mutual exchange of clinical and genetic information to speed up the identification and interpretation of clinically relevant gene mutations. Such consortia have been established for several genetic diseases (such as intellectual disability) in the past and have without doubt demonstrated their benefits.

In summary, we are confident that major breakthroughs will be achieved in the near future concerning the genetic causes of male infertility. Initially, this will certainly cover azoospermia, but in the middle term will be broadened to multifactorial conditions such as oligozoospermia. First of all, this will greatly help to im- prove our understanding of the molecular biology of spermatogenic failure. Clinically most important, novel genetic diagnostic procedures, initially most likely comprehensive gene sequencing, will be introduced into diagnostic routine. This will allow for more precise risk estimates, better counselling of couples, and evidence-based treatment decisions. Ultimately, elucidating the causes underlying male infertility and corresponding phenotypes will pave the way for novel, personalised treatment regimens improving patient/couple care and offspring health.

\section{Practical conclusion}

Screening for chromosomal aberrations and/or Y-chromosomal azoospermia factor deletions are currently still at the forefront of genetic diagnostics for infertile men with disorders of spermatogenesis, i.e. oligo- or azoospermia. However, preliminary data from our screening study on three candidate genes have already shown that using specific gene analyses, the aetiological clarification of disturbed spermatogenesis can be significantly improved. Furthermore, clinically relevant results are expected from the studies currently underway, which could then be introduced into routine diagnostics within the framework of a gene panel analysis, thus improving the guidance and treatment given to men/couples.

\section{Corresponding address}

Prof. Dr. med. F. Tüttelmann, MD

Institute of Human Genetics, University of Münster

Vesaliusweg 12-14, 48149 Münster, Germany frank.tuettelmann@ukmuenster.de

Acknowledgements. The authors are indebted to Yvonne Stratis (PhD), Margot Wyrwoll (MD), Corinna Friedrich (PhD), Matthias Vockel (PhD), Nils van der Bijl (cand. med.) who are integral parts of the author's working group on "Reproductive Genetics" and without whose continuous efforts the presented and cited data would not be available. We are very grateful for the constant support of Peter Wieacker (MD, Director of the Institute of Human Genetics) who approved and supported the development of this group within his institute.

All work was carried out in close collaboration with the colleagues at the Centre of Reproductive Medicine and Andrology (CeRA), Münster, who, ini- 
tiated by Ebo Nieschlag (MD), have been collecting data and materials from infertile men for decades and, thanks to Jörg Gromoll (PhD), with great foresight started to biobank samples (especially DNA) over 20 years ago, thus establishing a collection that is unique in its clinical detail and size. We especially thank Stefan Schlatt (PhD, Director) and Sabine Kliesch (MD, Head of Department of Clinical and Surgical Andrology) of the CeRA for their always constructive collaboration and for providing data and materials. The constant support of Claudia Krallmann (MD) in characterising, selecting and re-contacting patients is gratefully acknowledged, representative of many other clinicians at the CeRA.

Last not least, none of this work would have been possible without the patients who participated and consented to extended genomic analyses.

Funding. This work was supported by the Deutsche Forschungsgemeinschaft, Clinical Research Unit 'Male Germ Cells: from Genes to Function' (CRU326, grant TU 298/4-1).

\section{Compliance with ethical guidelines}

Conflict of interest. F. Tüttelmann, C. Ruckert and A. Röpke declare that they have no competing interests.

Approval was obtained from the Ethics Committee of the Medical Faculty in Münster. All participants gave informed written consent. The study was conducted in accordance with the Declaration of Helsinki in its most recent amended version.

Open Access. This article is distributed under the terms of the Creative Commons Attribution 4.0 International License (http://creativecommons.org/licenses/by/ 4.0/), which permits unrestricted use, distribution, and reproduction in any medium, provided you give appropriate credit to the original author(s) and the source, provide a link to the Creative Commons license, and indicate if changes were made.

\section{References}

1. Aston Kl, Carrell DT (2009) Genome-wide study of single-nucleotide polymorphisms associated with azoospermia and severe oligozoospermia. J Androl 30:711-725. https://doi.org/10.2164/ jandrol.109.007971

2. Aston KI, Krausz C, Laface I et al (2010) Evaluation of 172 candidate polymorphisms for association with oligozoospermia or azoospermia in a large cohort of men of European descent. Hum Reprod 25:1383-1397. https://doi.org/10.1093/humrep/ deq081

3. Bashamboo A, Ferraz-de-Souza B, Lourenço D et al (2010) Human male infertility associated with mutations in NR5A1 encoding steroidogenicfactor 1. Am J Hum Genet 87:505-512. https://doi.org/ 10.1016/j.ajhg.2010.09.009

4. Behre HM, Bergmann M, Simoni M, Tüttelmann $F$ (2015) Primary Testicular Failure. In: De Groot LJ, Chrousos G, Dungan K, Feingold KR, Grossman A, Hershman JM, Koch C, Korbonits M, McLachlan R, New M, Purnell J, Rebar R, Singer F, Vinik A (eds)
Endotext. MDText.com, Inc., South Dartmouth, p2000

5. Bergmann M, KlieschS (2010) Testicularbiopsyand histology. In: Nieschlag E, Beere HM, Nieschlag S (eds) Andrology-Male Reproductive Health and Dysfunction. Springer, Heidelberg, pp 155-167

6. Boehm U, Bouloux P-M, Dattani MT et al (2015) Expert consensus document: European Consensus Statement on congenital hypogonadotropic hypogonadism - pathogenesis, diagnosis and treatment. Nat Rev Endocrinol 11:547-564. https://doi.org/10.1038/nrendo.2015.112

7. Chalmel F, Lardenois A, Evrard B et al (2012) Global human tissue profiling and protein network analysis reveals distinct levels of transcriptional germline-specificity and identifies target genes for male infertility. Hum Reprod 27:3233-3248. https://doi.org/10.1093/humrep/des301

8. Chassaing N, PatatO, Pagin Aetal (2016) Truncating mutations in the adhesion $G$ protein- coupled receptor G2 gene ADGRG2 cause an X-linked congenital bilateral absence of vas deferens. Am J Hum Genet 99:437-442. https://doi.org/10.1016/ j.ajhg.2016.06.012

9. Choi $Y$, Jeon S, Choi M et al (2010) Mutations in SOHLH1 gene associate with nonobstructive azoospermia. Hum Mutat 31:788-793. https://doi. org/10.1002/humu.21264

10. Dalgaard MD, Weinhold N, Edsgärd D et al (2012) A genome-wide association study of men with symptoms of testicular dysgenesis syndrome and its network biology interpretation. J Med Genet 49:58-65. https://doi.org/10.1136/jmedgenet2011-100174

11. Ferlin A, Raicu F, Gatta V et al (2007) Male infertility: role of genetic background. Reprod Biomed Online 14:734-745. https://doi.org/10.1016/ S1472-6483(10)60677-3

12. Ferlin A, Rocca MS, VinanziCetal (2015) Mutational screening of NR5A1 gene encoding steroidogenic factor 1 in cryptorchidism and malefactorinfertility and functional analysis of seven undescribed mutations. Fertil Steril 104:163-169.e1. https:// doi.org/10.1016/j.fertnstert.2015.04.017

13. Ferraz-de-Souza B, Lin L, Achermann JC (2011) Steroidogenic factor-1 (SF-1, NR5A1) and human disease. Mol Cell Endocrinol 336:198-205. https:// doi.org/10.1016/j.mce.2010.11.006

14. Gershoni M, Hauser R, Yogev L et al (2017) A familial study of azoospermic men identifies three novel causative mutations in three new human azoospermia genes. Genet Med:1-9. https://doi org/10.1038/gim.2016.225

15. Lo Giacco D, Chianese C, Ars Eet al (2014) Recurrent $X$ chromosome-linked deletions: discovery of new genetic factors in male infertility. J Med Genet 51:340-344. https://doi.org/10.1136/jmedgenet2013-101988

16. Gianotten J, Westerveld GH, Leschot NJ et al (2004) Familial clustering of impaired spermatogenesis: no evidence for a common genetic inheritance pattern. Hum Reprod 19:71-76

17. van Golde RJT, van der Avoort IAM, Tuerlings JHAM et al (2004) Phenotypic characteristics of male subfertility and its familial occurrence. J Androl 25:819-823

18. Hu Z, Li Z, Yu J et al (2014) Association analysis identifies new risk loci for non-obstructive azoospermia in Chinese men. Nat Commun 5:3857. https://doi.org/10.1038/ncomms4857

19. Kaplan E, Shwachman H, Perlmutter AD et al (1968) Reproductive failure in males with cystic fibrosis. N Engl J Med 279:65-69. https://doi.org/10.1056/ NEJM196807112790203
20. Kosova G, Scott NM, Niederberger $C$ et a (2012) Genome-wide association study identifies candidate genes for male fertility traits in humans. Am J Hum Genet 90:950-961. https://doi.org/10. 1016/j.ajhg.2012.04.016

21. Krausz C, Escamilla AR, Chianese C (2015) Genetics of male infertility: from research to clinic Reproduction 150:R159-R174. https://doi.org/10. 1530/REP-15-0261

22. Krausz C, Hoefsloot L, Simoni M, Tüttelmann $F$ (2014) EAA/EMQN best practice guidelines for molecular diagnosis of $\mathrm{Y}$-chromosomal microdeletions: state-of-the-art 2013. Andrology 2:5-19. https://doi.org/10.1111/j.2047-2927. 2013.00173.x

23. Ledig S, Hiort O, Scherer G et al (2010) ArrayCGH analysis in patients with syndromic and nonsyndromic $\mathrm{XY}$ gonadal dysgenesis: evaluation of array CGH as diagnostic tool and search for new candidate loci. Hum Reprod 25:2637-2646. https://doi.org/10.1093/humrep/deq167

24. de Ligt J, Willemsen MH, van Bon BWM et al (2012) Diagnostic exome sequencing in persons with severe intellectual disability. $\mathrm{N}$ Engl J Med 367:1921-1929. https://doi.org/10.1056/ NEJMoa1206524

25. Lilford R, Jones AM, Bishop DT et al (1994) Casecontrol study of whether subfertility in men is familial. BMJ 309:570-573

26. Lima AC, Carvalho F, Gonçalves J et al (2015) Rare double sex and mab-3-related transcription factor 1 regulatory variants in severe spermatogenic failure. Andrology 3:825-833. https://doi.org/10. 1111/andr.12063

27. Lopes AM, Aston Kl, Thompson E et al (2013) Human spermatogenic failure purges deleterious mutation load from the autosomes and both sex chromosomes, including the gene DMRT1. Plos Genet 9:e1003349. https://doi.org/10.1371/ journal.pgen.1003349

28. Matzuk MM, Lamb DJ (2008) The biology of infertility: research advances and clinical challenges. Nat Med 14:1197-1213. https://doi. org/10.1038/nm.f.1895

29. McLachlan RI, O'Bryan MK (2010) Clinical review: state of the art for genetic testing of infertile men. J Clin Endocrinol Metab 95:1013-1024. https:// doi.org/10.1210/jc.2009-1925

30. Nuti F, Krausz C (2008) Gene polymorphisms/ mutations relevant to abnormal spermatogenesis. Reprod Biomed Online 16:504-513

31. Okutman O, Muller J, Baert $Y$ et al (2015) Exome sequencing reveals a nonsense mutation in TEX15 causing spermatogenic failure in a Turkish family. Hum Mol Genet 24:5581-5588. https://doi.org/10. 1093/hmg/ddv290

32. Punab M, Poolamets O, Paju Pet al (2017) Causes of male infertility: a 9-year prospective monocentre study on 1737 patients with reduced total sperm counts. Hum Reprod 32:18-31. https://doi.org/10 1093/humrep/dew284

33. Ramasamy R, Bakırcıoğlu ME, Cengiz $C$ et al (2015) Whole-exome sequencing identifies novel homozygous mutation in NPAS2 in family with nonobstructive azoospermia. Fertil Steril 104:286-291. https://doi.org/10.1016/j.fertnstert. 2015.04.001

34. Rauch A, Wieczorek D, Graf E et al (2012) Range of genetic mutations associated with severe nonsyndromic sporadic intellectual disability: an exome sequencing study. Lancet 380:1674-1682. https://doi.org/10.1016/S0140-6736(12)61480-9 
35. Rehm HL (2017) Evolving health care through personal genomics. Nat Rev Genet 18:259-267. https://doi.org/10.1038/nrg.2016.162

36. Richards S, Aziz N, Bale S et al (2015) Standards and guidelines for the interpretation of sequence variants: a joint consensus recommendation of the American College of Medical Genetics and Genomics and the Association for Molecular Pathology. Genet Med 17:405-423. https://doi. org/10.1038/gim.2015.30

37. Röpke A, Tewes A-C, Gromoll J et al (2013) Comprehensive sequence analysis of the NR5A1 gene encoding steroidogenic factor 1 in a large group of infertile males. Eur J Hum Genet 21:1012-1015. https://doi.org/10.1038/ejhg. 2012.290

38. Sato Y, Jinam T, Iwamoto T et al (2013) Replication study and meta-analysis of human nonobstructive azoospermia in Japanese populations. Biol Reprod 88:87. https://doi.org/10.1095/biolreprod.112. 106377

39. Schultz N, Hamra FK, Garbers DL (2003) A multitude of genes expressed solely in meiotic or postmeiotic spermatogenic cells offers a myriad of contraceptive targets. Proc Natl Acad Sci USA 100:12201-12206. https://doi.org/10.1073/pnas. 1635054100

40. Simoni M, Tüttelmann F, Gromoll J, Nieschlag E (2008) Clinical consequences of microdeletions of the $Y$ chromosome: the extended Münster experience. Reprod Biomed Online 16:289-303. https://doi.org/10.1016/S1472-6483(10)60588-3

41. Stamou MI, Cox KH, Crowley WF (2015) Discovering genes essential to the hypothalamic regulation of human reproduction using a human disease model: adjusting to Life in the "-omics" era. Endocr Rev36:603-621. https://doi.org/10.1210/er.20151045

42. Stouffs K, LissensW, Tournaye Hetal (2005) Possible role of USP26 in patients with severely impaired spermatogenesis. Eur J Hum Genet 13:336-340. https://doi.org/10.1038/sj.ejhg.5201335

43. Tewes A-C, Ledig S, Tüttelmann F et al (2014) DMRT1 mutations are rarely associated with male infertility. Fertil Steril 102:816-820. https://doi. org/10.1016/j.fertnstert.2014.05.022

44. Tournaye H, Krausz C, Oates RD (2016) Novel concepts in the aetiology of male reproductive impairment. Lancet Diabetes Endocrinol. https:// doi.org/10.1016/S2213-8587(16)30040-7

45. Tournaye H, Krausz C, Oates RD (2016) Concepts in diagnosis and therapy for male reproductive impairment. Lancet Diabetes Endocrinol. https:// doi.org/10.1016/S2213-8587(16)30043-2

46. Tüttelmann F, Luetjens CM, Nieschlag E (2006) Optimising workflow in andrology: a new electronic patient record and database. Asian J Androl 8:235-241. https://doi.org/10.1111/j. 1745-7262.2006.00131.x

47. Tüttelmann F, Rajpert-De Meyts E, Nieschlag E et al (2007) Gene polymorphisms and male infertility - a meta-analysis and literature review. Reprod Biomed Online 15:643-658. https://doi. org/10.1016/S1472-6483(10)60531-7

48. Tüttelmann F, Röpke A (2017) Genetics of male infertility. In: Endocrinol. Testis male reprod, pp 1-21

49. Tüttelmann F, Simoni M, Kliesch S et al (2011) Copy number variants in patients with severe oligozoospermia and sertoli-cell-only syndrome. PLoS ONE 6:e19426. https://doi.org/10.1371/ journal.pone.0019426

50. Tüttelmann F, Werny F, Cooper TG et al (2011) Clinical experience with azoospermia: aetiology and chances for spermatozoa detection upon biopsy. Int J Androl 34:291-298. https://doi.org/ 10.1111/j.1365-2605.2010.01087.x

51. Veltman JA, Brunner HG (2012) De novo mutations in human genetic disease. Nat Rev Genet 13:565-575. https://doi.org/10.1038/nrg3241

52. Vinci G, Chantot-Bastaraud S, El Houate B et al (2007) Association of deletion 9p, 46,XY gonadal dysgenesis and autistic spectrum disorder. Mol Hum Reprod 13:685-689. https://doi.org/10. 1093/molehr/gam045

53. Vogt PH (2004) Molecular genetics of human male infertility: from genes to new therapeutic perspectives. Curr Pharm Des 10:471-500

54. Vogt PH, Edelmann A, Kirsch S et al (1996) Human $Y$ chromosome azoospermia factors (AZF) mapped to different subregions in Yq11. Hum Mol Genet 5:933-943. https://doi.org/10.1093/hmg/5.7.933

55. World Health Organization (2010) WHO laboratory manual for the examination and processing of human semen. 5th ed. WHOPress, Geneva.

56. World Health Organization (2017) Infertility is a global public health issue. http://www. who.int/reproductivehealth/topics/infertility/ perspective/en/. Accessed 16.12.2017

57. Yan W (2009) Male infertility caused by spermiogenic defects: lessons from gene knockouts. Mol Cell Endocrinol 306:24-32. https://doi.org/10. 1016/j.mce.2009.03.003

58. Yang F, Silber S, Leu NA et al (2015) TEX11 is mutated in infertile men with azoospermia and regulates genome-wide recombination rates in mouse. Embo Mol Med 7:1198-1210. https://doi. org/10.15252/emmm.201404967

59. Yatsenko AN, Georgiadis AP, Röpke A et al (2015) X-linked TEX11 mutations, meiotic arrest, and azoospermia in infertile men. N Engl J Med 372:2097-2107. https://doi.org/10.1056/ NEJMoa1406192

60. Zhao H, Xu J, Zhang H et al (2012) A genomewide association study reveals that variants within the HLA region are associated with risk for nonobstructive azoospermia. Am J Hum Genet 90:900-906. https://doi.org/10.1016/j.ajhg.2012 04.001
Die Rolle genetischer Veränderungen des Hormons Prolaktin bei Netzhaut- und Herzerkrankungen

Wissenschaftler aus Nürnberg haben herausgefunden, dass genetische Veränderungen des Hormons Prolaktin einen Einfluss auf die Entstehung und den Verlauf von Erkrankungen der Netzhaut und des Herzens haben können.

In einer bioinformatischen Analyse stellten die Wissenschaftler fest, dass genetisch bedingte Änderungen von einzelnen Aminosäuren des auch als "Stillhormon" bekannten Prolaktins, sog. Punktmutationen, die enzymatische Spaltung des Prolaktins, und somit die Menge der ProlaktinSpaltprodukte vermehren oder vermindern können. Die Prolaktin-Spaltprodukte, sog. Vasoinhibine, regulieren verschiedene Funktionen von Blutgefäßen. Diese sind sowohl bei Netzhauterkrankungen von Patienten mit Diabetes Mellitus (Diabetische Retinopathie und Makula- Ödem), als auch bei einer seltenen Form der Herzschwäche, die bei schwangeren Frauen oder stillenden Müttern auftreten kann (PeripartumKardiomyopathie), gestört.

Für diese Störung der Blutgefäßfunktionen können verminderte oder vermehrte Vasoinhibin-Mengen verantwortlich sein, die infolge der Mutationen im ProlaktinGen entstehen können. Deshalb könnten Veränderungen des Prolaktin-Gens, je nach Art der Mutation, eine schützende Rolle spielen oder aber einen Risikofaktor darstellen. Eine praktische Konsequenz für Patienten geht aus dieser Studie derzeit nicht hervor, da die Ergebnisse zunächst in experimentellen und klinischen Studien mit Patienten bestätigt werden müssen.

Literatur: Triebel J, Friedrich CJ, Leuchs A et al (2017) Human Prolactin Point Mutations and Their Projected Effect on Vasoinhibin Generation and Vasoinhibinrelated Diseases. Front. Endocrinol. https://doi.org/10.3389/fendo.2017.00294

Quelle: Paracelsus Medizinische Privatuniversität, Standort Nürnberg, www.pmu.ac.at/nuernberg 